\title{
E-Learning in Higher Education for Adult Learners in Singapore
}

\author{
Chong Guan, Ding Ding, and Kong Weng Ho
}

\begin{abstract}
Countries across the world have witnessed tremendous expansion of adult education and dramatic growth of adult learners. Moreover, with the growing importance of life-long learning, online learning has become a popular tool which is well received by adult learners. In order to enhance adult learners' learning experience, we have conducted an exploratory research on online learning for adult learners to understand the challenges faced by them in their pursuit of higher education. The results suggest that technical trainings or preparations are needed prior to e-learning and infrastructure needs to be improved. The findings also emphasize on the importance of using localized examples and cases for class discussion.
\end{abstract}

Index Terms-Adult learning, e-learning, higher education.

\section{INTRODUCTION}

With the widespread upgrading needs in the recent decades, higher education is increasingly embraced by adult learners. Countries across the world have witnessed tremendous expansion of adult education and dramatic growth of adult learners [1]. In the United States, National Center for Education Statistics (NCES) data indicate that 38 percent of the enrollment of college students were twenty-five years of age or older in the year 2007 and the projected enrollment from 2007-2018 will remain stable or increase [2]. Other countries with high percentages of adult learners who participate in college/university degree programs include Australia, Canada, United Kingdom, Norway, Sweden, and Israel, each representing 30\% or more of the total tertiary enrolments [1], [3]. Higher education for adult learners has attracted the attention of both researchers and practitioners.

Moreover, with the growing importance of life-long learning, online learning has become a popular tool which is well received by adult learners. Online learning allows flexibly in learning and accessing materials according to students' needs. Compared with traditional courses, online learning provides more interactive materials that allow easy access to information and feedback from students. Currently, most established universities have incorporated online learning in their teaching to accommodate the diverse need in learning. Studies have shown that many college students have experienced online learning either delivered completely

Manuscript received March 2, 2014; revised May 12, 2014.

Chong Guan and Ding Ding are with the School of Business, SIM University, CO 599491 Singapore (e-mail: guanchong@unisim.edu.sg; dingding@unisim.edu.sg).

Kong Weng Ho is with Faculty of Arts and Social Sciences, National University of Singapore, Singapore (e-mail: kwho@nus.edu.sg). online or through hybrid models that combine face to face learning with an online component [4]. The NECS report also shows that at least two-thirds of degree-granting institutions offered online courses, blended/hybrid courses, or courses offered in other distance education formats for college-level credit [5]. The most common reason to offer distance education courses or programs was meeting student demand for flexible schedules, as reported by 68 percent of the institutions. Nearly two-thirds of institutions reported an interest in providing access to college for students who do not otherwise have access.

In Singapore, the courses that provide working adults opportunities for continuing education are emerging. There are numerous universities offering opportunities for part-time degree courses at both undergraduate and postgraduate level. Moreover, government subsidies and financial assistance schemes are available to support eligible adult learners pursuing higher education. However, in spite of the growth in adult learners and the availability of new technologies that assists learning, the high attrition rate has been of concern to many higher education institutions. Research shows that many adult learners constantly have to compromise between their competing priorities which constitute their studies, work, families and other personal commitments [1]. These roles may be assets, both through the social support they provide and through the rich life experiences that make meaning of theoretical constructs that could be purely abstract to high school leavers. Yet more often, these multiple roles present challenges in students' allocation of time for both academic study and participation in campus-based activities and increase the likelihood they will discontinue their study.

In order to enhance adult learners' learning experience, we have conducted an exploratory research on online learning for adult learners to understand the challenges faced by them in their pursuit of higher education. In the current research, we define the adult learners in higher education by using chronological age and additional factors such as delayed university enrollment, part-time attendance, working experience or full-time work while enrolled, and financial independence [6]. This study is one of the first empirical investigations on adult learners' perceptions of online learning within the higher education sectors among developed economies in Asia. In essence, we aim to address three very important questions pertaining to online learning for adult learners: 1) Learn how to deliver classes effectively without face-to-face meetings; 2) Assess the suitability of various on-learning tools and course materials for adult learners: and 3) Understand the challenges from the perspectives of adult students in their e-learning journey.

The findings of this research have practical implications in many folds: Firstly, it provides a better understanding of the 
challenges faced by adult learners and thus enable higher education institutions to make adjustments in the relevant aspects to improve students' learning experience. Secondly, by investigating the various online-learning tools and course materials, it attempts to shed light on the most effective approaches to provide online learning context that nurtures adult students' engagement in learning. Finally, the findings can also be used for enhancing the curriculum in the higher education institutions to maintain and/or enhance their competitive position.

\section{LITERATURE REVIEW}

\section{A. Theories of Adult Learning}

Previous studies on adult education can be classified into two categories: how adults learn, and the characteristics of adult learners. Research in these areas has provided insight into ways in which institutions can cater course delivery formats to accommodate the needs of adult learners, and the characteristics of these learners within the traditional face-to-face or distance education environment [7].

However, many of such studies do not differentiate adult higher education from workforce development / training programs, and human resource development. Besides, most studies were conducted in the Western countries such as the Unite States [1], [8]. In the Asian region, initial attempts in adult education were primarily focused on imparting basic literacy skills [9]. Adult learners' perceptions in the higher education e-learning have not been well investigated, particularly for the developed countries in Asia such as Singapore.

Several theoretical approaches to adult learning have served as useful lenses for understanding adult learners. Andragogy is one of the most important theoretical approaches to motivation of adult learning, described as the art and science of helping adults learn [10]. According to Knowles [10], andragogy (Greek: "man-leading") should be distinguished from the more commonly used pedagogy (Greek: "child-leading"). The practice of Andragogy, unlike pedagogy, puts the focus on the learner - the adult — and not on the teacher.

According to this framework, adults are assumed to a) prefer self-directed learning, $b$ ) bring experience to learning activities, c) be responsible for their decisions on education, d) exhibit an orientation to learning that is task or problem-centered, and e) exhibit a relatively high degree of internal motivation [10], [11]. This framework is one of the most enduring and widely cited theories of adult learning [12]. However, the theory of andragogy has been widely debated. Researchers note that the situational variables also influence the degree to which adult learners exhibit these characteristics [13].

Other adult learning theories center on a key assumption of andragogy-self-directed learning (SDL). The SDL theory posits that educational goals within formal education could be supported by using teaching methods designed to increase learner control relative to that of instructors [14], [15].

In the past twenty years, transformative learning (TL) has become one of the most prominent theories in adult learning research [16]. TL involves disorienting dilemmas - situations that challenge adults' previous ways of thinking and prompt them to reflect critically on previously held assumptions [16]. Research on TL have proposed that educators can facilitate and stimulate transformative learning by using teaching methods that foster critical reflection [17].

A number of studies have explored the characteristics of adult learners in the traditional face-to-face setting. For example, Ross-Gordon [7] focuses on the needs of adult students, including their preferences for active learning strategies that support cognitive growth and transformational learning, and their desires for immediate application of knowledge; and opportunities for self-directed learning. Research also shows that the lack of self-confidence often exhibited by adult learners and their frequent desire for highly structured learning experiences provides a clear roadmap of teacher expectations. This body of research suggests that while adult learners desire flexibility, they also often desire structure [7].

\section{B. Adult Learners in Online Education}

New developments in the information technology and communication systems have resulted in a new paradigm change for knowledge delivery - the online learning. In literature, different terminologies have been used in the explanation of online learning. Terms that are commonly used include e-learning, Internet learning, virtual learning, computer-assisted learning, Web-based learning, and distance learning. Although there is no consensus on the exact definition of online learning, it is generally accepted that learning content can be offered in different format, such as text or video images, and electronically delivered via the Internet, personal computer, CD-ROM or mobile devises [18]. To date, online learning has received considerable attention as a means of providing alternatives to traditional face-to-face, instructor-led education [19]. Online teaching offers vast opportunities to expand the learning environment for the diverse student population [20]. Furthermore, online learning allows students to participate regardless of geographic location, independent of time and place [21].

Belanger and Jordan [22] reported three ways in which the technologies may be employed in educational organizations as they evolve through stages. The first stage is technology insertion, which happens when the organization is interested in using instructional technologies within the traditional classroom environment. The second stage is partial conversion, in which parts of courses are delivered online or through other distance-learning technologies. The third stage is total conversion, which is the most extensive conversion of traditional classroom training to online or other distance-learning technologies. Allen and Seaman [23] divided courses into four categories pertaining to the percentage of content taught online. The first category refers to traditional or courses without online technologies $(0 \%)$, with all content delivered in writing or orally. The second category includes web-facilitated courses that use web-based technologies, such as the Learning Management System (LMS) or web pages, to facilitate what is essentially a face-to-face course. This method delivers between $1 \%$ and $29 \%$ of course content through online means in support of the learning process. The third category consists of blended/hybrid courses that combine online and face-to-face 
delivery, with substantial proportion $(30 \%$ to $70 \%)$ of the content delivered online. The fourth category comprises online courses where most $(80 \%$ or more) or all content is delivered online. This last category typically has no face-to-face meetings.

Although online learning practices are divided into different categories, previous studies agree that the approach provides numerous advantages for the effectiveness of teaching and learning. Online learning provides flexibility in learning and accessing materials according to student needs in terms of time and techniques. Similarly, compared to traditional courses, online learning provides interactive materials that allow easy access to information and feedback from others. However, not all students are interested to engage in online learning, especially those who study courses that require a face-to-face environment, such as engineering. According to Junaidu [24], the idiosyncrasies of some science and engineering-based courses limit the adoption of online education, compared with the wide usage in other fields. In addition, Diaz and Cartnal [25] suggest that this situation relates to learning styles. Students with different learning styles will have different perceptions and commitment towards online learning. Many researchers believe that students do not learn in the same way, which can lead to different styles. Learning style can also change according to experience.

Learning activity in online learning is based on learner autonomy and interactive learning actions [26]. Interaction between teachers and students leads to students' satisfaction and students learning outcome [27]. Sun et al. [28] define learner attitude as "learner impression of participating in e-learning activities through computer usage". Some researcher believe that learner attitude play a significant role. This is because online learning environment allow students to arrange their own learning. Students are required to take a more active role in their learning as online learning environment is not teacher-centred. Students may engage in online learning, control the learning time and procedures by themselves (Liaw, Huang and Chen, 2007). Ho and Kuo [29] argue that learner's computer attitudes play a significant role in the usability of online learning. Prior studies have shown that attitude and self-efficacy have been identified as important factors that affect learner's motivation, interest and performance in internet based learning environments [30]. Piccoli et al. [31] find that when learner are not afraid of complexity in information technology (positive attitude), learner will become more satisfied and effective in online learning.

Learner attitude toward online learning also depend on system characteristic. Pituch and Lee [32] from their empirical studies indicate that learners have greater intention to use the system if the system is user friendly. Their research also shows that systems that enable learner to interact effectively and offer access to course content at the time influencing student to use the system for their learning. As noted by Selim [33], learner's attitude to engage in online learning is also related to his/her previous knowledge in using computer. In addition, learner's attitude toward internet is also important to determine learner's motivation, interest and performance in online learning environment [34].

Furthermore, there are also researchers studying how online learning affects students' learning experience. Fich \& Hiltz [35] suggests that combining group work with asynchronous learning networks improves students' perception of learning. Hanson \& Robson [36] believe the learning management systems develop learning perceptions positively. In their research on student experiences in discussion environments, Ellis et al. [37] find that students can manage learning better in online discussion environments. In their research on student perception related to the use of learning management system, Lonn \& Teasley [38] suggest that the use of communication technologies improve learning perception. Roehm \& Bonnel [39] found that the role of teachers and educational institution are important and providing useful experiences through interaction is vital.

\section{Research Framework}

The prior research in the area of students' choice of universities by Woodruff, Cadotte and Jenkins [40] and Cadotte, Woodruff and Jenkins [41] suggests that the students compare their experiences with a set of expectations. As compared to fresh school leavers, adult students have different expectations, abilities and motivations. On the other hand, the university staff also forms some idea of the expectations that the students bring and how these are being fulfilled.

\section{METHODS}

The aim of this study is to explore adult learners and instructors' perception towards e-learning in tertiary education. Specifically, the objectives of the study include

1) Learning how to deliver classes without face-to-face meetings; and 2) Assessing the suitability of e-learning materials. In achieving this aim, and in view of the formative nature of the field of enquiry, an exploratory research approach was adopted. The research was focused on an area of enquiry, where phenomena are not well understood

\section{A. Data Collection}

Given the emergent nature of the research problem, we adopted both focus group interviews and semi-structured surveys as data collection tools. 36 adult learners were randomly assigned to one of the 8 e-learning courses in the business school of a major university in Singapore. They then attended the respective courses once a week for six weeks. All the courses are conducted online without face-to-face seminars. They are also given e-learning materials including the textbook, study guide, chunked lectures and step-by-step study example. Chunked lectures are short videos of narrated PowerPoint slides that are between 10 to 15 minutes in length. The online activities include online discussion board, individual and group-based assignments, synchronized web seminars (webinars) and online quiz. At the end of the course, they were invited to participate in a survey and a focus group discussion. A focus group discussion was also conducted with the eight instructors. The findings from the survey and focus group discussions are presented in the next section. 


\section{RESUlTS AND DisCUSSION}

\section{A. Results on Adult Learners' Perceptions of e-Learning Materials}

The findings on adult learners are organized around three sub-sections, the materials, the activities and the learners. Among the 36 adult learner respondents, $55.56 \%$ of them are male and $44.44 \%$ are female. Majority of them $(47.22 \%)$ fall between the ages of 45 to $54.22 .78 \%$ are between 25 to 34 years old and $22.22 \%$ are between $35-44$ years old. Only $2.78 \%$ are above 55 years old.

In the survey, the student participants are first asked whether they agree with the statement that "The following learning materials are helpful in my learning". Table I shows the adult learners perception of the helpfulness of the e-learning materials. None of the respondent chose the "strongly disagree" anchor. The result shows that most of the participants perceived the various e-learning materials provided to be rather helpful. Among the e-learning materials, all respondents agreed that the textbook is helpful and $97.37 \%$ of them thought that online chunked lectures are helpful. For study guides (91.43\%) and CD/DVDs (89.28\%), close to $90 \%$ of the respondents chose "agree" or "strongly agree" options. However, about one quarter (26.31\%) of the respondents had some doubts about the helpfulness of e-textbooks.

TABLE I: HELPFULNESS OF THE E-LEARNING MATERIALS

\begin{tabular}{lllll}
\hline \hline Materials & Disagree & Neutral & Agree & $\begin{array}{l}\text { Strongly } \\
\text { Agree }\end{array}$ \\
\hline Textbook & $0 \%$ & $0 \%$ & $58.97 \% *$ & $41.03 \%$ \\
E-textbook & $5.26 \%$ & $21.05 \%$ & $57.89 \%$ & $15.79 \%$ \\
Study Guide & $2.86 \%$ & $5.71 \%$ & $42.86 \%$ & $48.57 \%$ \\
Online Lectures & $2.63 \%$ & $0 \%$ & $65.79 \%$ & $31.58 \%$ \\
CD/DVD & $3.57 \%$ & $7.14 \%$ & $57.14 \%$ & $32.14 \%$ \\
\hline \hline
\end{tabular}

Note. * The percentage of respondents choosing the option.

Based on the qualitative responses through focus groups, we identified characteristics of e-learning materials that respondents are satisfied with and areas where improvements are needed.

First of all, the qualitative responses further confirm some of the survey findings. For example, many expressed their satisfaction towards online chunked lectures. One of the comments was, "The online study unit... let us experience the wonder of multimedia lecture". Another mentioned that "Recorded explanations of topics covered are very useful. Students will be able to log into the website to learn at their own available time".

At the same time, some also pointed out that although the chunked lectures are useful, some improvements needed to increase its efficiency and effectiveness. Some of the suggestions include providing downloadable slides with scripts; creating better social presence of the instructor; more lively presentations and technical issues such as the clarity, speed and volume of voice.

Clearly, participants favour contextualized materials. A typical comment was, "Good to have more materials with local or Asian context".

One of the common issues that many are facing is the multiple e-learning materials. Respondents felt that there was an overlap between textbook, study guide and chunked lectures. One commented that "If these could be streamlined then that would improve the course materials". Some mentioned that they found that the study guides are sufficient and they ended up using less of the textbook, although it is more "extensive".

\section{B. Results on Adult Learners' Perceptions of e-Learning Activities}

In the survey, the student participants are then asked whether they agree with the statement that "The following learning activities are helpful in my learning". Table II tabulates the adult learners' perceptions of the e-learning activities. The result shows that majority of the participants perceived the e-learning activities provided to be rather helpful. All participants agreed that case study is a useful e-learning activity. However, close to $10 \%$ of the respondents do not think that Non-graded synchronized Discussion Board, live webinar, online formative quiz on blackboard learning system are helpful in the learning process.

TABLE II: HELPFULNESS OF THE E-LEARNING ACTIVITIES

\begin{tabular}{|c|c|c|c|c|c|}
\hline Activities & $\begin{array}{l}\text { Strongly } \\
\text { Disagree }\end{array}$ & Disagree & Neutral & Agree & $\begin{array}{l}\text { Strongly } \\
\text { Agree }\end{array}$ \\
\hline $\begin{array}{l}\text { Non-graded } \\
\text { syn. DB }\end{array}$ & $4.35 \% *$ & $4.35 \%$ & $13.04 \%$ & $47.83 \%$ & $30.43 \%$ \\
\hline $\begin{array}{l}\text { Non-graded } \\
\text { asyn. DB }\end{array}$ & $0 \%$ & $3.70 \%$ & $22.22 \%$ & $48.15 \%$ & $25.93 \%$ \\
\hline $\begin{array}{l}\text { Graded } \\
\text { asyn. DB }\end{array}$ & $0 \%$ & $3.57 \%$ & $14.29 \%$ & $50.00 \%$ & $32.14 \%$ \\
\hline $\begin{array}{l}\text { Indi. } \\
\text { Assign. }\end{array}$ & $0 \%$ & $0 \%$ & $8.33 \%$ & $50.00 \%$ & $41.67 \%$ \\
\hline GBA & $0 \%$ & $0 \%$ & $18.18 \%$ & $50.00 \%$ & $31.82 \%$ \\
\hline $\begin{array}{l}\text { Live } \\
\text { webinar }\end{array}$ & $3.57 \%$ & $3.57 \%$ & $17.86 \%$ & $50.00 \%$ & $25.00 \%$ \\
\hline $\begin{array}{l}\text { Recorded } \\
\text { webinar }\end{array}$ & $0 \%$ & $5.56 \%$ & $16.67 \%$ & $55.56 \%$ & $22.22 \%$ \\
\hline $\begin{array}{l}\text { Formative } \\
\text { quiz in } \mathrm{BB}\end{array}$ & $3.57 \%$ & $3.57 \%$ & $7.14 \%$ & $50.00 \%$ & $35.71 \%$ \\
\hline $\begin{array}{l}\text { Formative } \\
\text { quiz from } \\
\text { publisher }\end{array}$ & $0 \%$ & $0 \%$ & $23.53 \%$ & $52.94 \%$ & $23.53 \%$ \\
\hline $\begin{array}{l}\text { Summative } \\
\text { quiz }\end{array}$ & $0 \%$ & $5.26 \%$ & $5.26 \%$ & $68.42 \%$ & $21.05 \%$ \\
\hline Case study & $0 \%$ & $0 \%$ & $0 \%$ & $72.22 \%$ & $27.78 \%$ \\
\hline $\begin{array}{l}\text { Step-by-step } \\
\text { examples }\end{array}$ & $0 \%$ & $0 \%$ & $9.52 \%$ & $38.10 \%$ & $52.38 \%$ \\
\hline
\end{tabular}

Note. $*$ The percentage of respondents choosing the option.

In the qualitative responses, the participants provided many suggestions of improvements. Live webinar is the most mentioned topic among all the e-learning activities. Majority of the respondents indicated that web seminars may be useful when there is system consistency, sufficient technical support, students having microphones and compatible systems and small class sizes.

The suggestions on live webinar include: instructors should set some house rules, e.g., relevant comments only; Instructors' slides should incorporate more visual props like videos or pictures; Instructors should try to bring the discussion back to the theoretical models. One typical comment was, "I think the live webinars can be livelier to 
encourage participation and to engage students. Perhaps having some examples using slides with graphics to illustrate points within the case (discussed)".

Other comments on live webinar include technical issues such as system compatibility (for Mac and Linux users), time delay in requesting and receiving a microphone to speak and the chat box function as a distraction. One typical comment was, "Public chats are very distracting and overwhelming for the instructors. When a student takes too long to type, the discussion flow is broken".

Participants also mentioned that both webinars and discussion boards are useful consultation tools. Some also mentioned that "instructors should link to real-life Singapore situations to encourage discussions".

\section{Results on Critical Factors for Adult Learners in e-Learning}

In the survey, self-discipline was ranked as the most important factor for adult learners, followed by study materials and the instructor (see Table III).

TABLE III: CRITICAL FACTORS OF E-LEARNING

\begin{tabular}{ll}
\hline \hline Factor & Modal Rank \\
\hline Study materials & 2 \\
Course mates & 7 \\
Instructor & 3 \\
Self-discipline & 1 \\
Technical support from Helpdesk & 6 \\
My own technical competence & 5 \\
Network access and stability & 4 \\
\hline \hline
\end{tabular}

Participants also shared their experience as adult learners in the focus group. Many commented that self discipline and effective time management is very important for students participating in an e-learning course. One comment was, "most of the time, we found ourselves lagging behind...it is due to heavy work and social commitments. Sometimes we were not able to participate in the live webinars because of other work commitments".

\section{Results on e-Learning Instructors}

A focus group discussion was conducted with the eight instructors. Regarding to the e-learning materials, the instructors commented that the textbooks were easier to follow than the study guide, which is different from the students' comments. The instructors also commented that although textbook publishers usually provide pre-existing chunked lectures, they do not cover all the learning outcomes Thus, they suggested that "recording chucked lectures and ensure all materials are in line with each other". Yet, they also recognized that though chunked lectures have good potentials in replacing lecturing, they may not be able to replace discussions.

Regarding the e-learning activities, the instructors were concerned about the low participation rate, especially for the non-graded components, such as the non-graded discussion board and webinars. They suggested incentives to encourage participation. They also recognized the difficulty in online environment. One typical comment was, "it is difficult to engage students in the discussion. Not able to control students well. Students are easily distracted".

\section{CONCLUSION}

Conceptually, this study provides the understanding of e-learning perceptions of Asian adult learners within the higher education sectors. The results suggest that technical trainings or preparations are needed prior to e-learning and infrastructure needs to be improved. The findings also emphasize on the importance of using localized examples and cases for class discussion.

The practical implications include strategic planning by the management and enhancing the curriculum and raising standards at the instructor level on various specific aspects, such as materials and activities.

\section{REFERENCES}

[1] C. Kasworm, "The influence of the knowledge society: trends in adult higher education," Journal of Continuing Higher Education, vol. 59, pp. 104-107, 2011 .

[2] W. Hussar and T. M. Bailey. (2009). Projections of Education Statistics to $2018 . \quad$ [Online]. Available: http://nces.ed.gov/programs/projections/projections2018/

[3] C. Kasworm, "Adult higher education from an international perspective," Higher Education, vol. 25, pp. 411-423, 1993.

[4] G. Bradford and S. Wyatt, "Online learning and student satisfaction: Academic standing, ethnicity and their influence on facilitated learning, engagement, and information fluency," The Internet and Higher Education, vol. 13, pp. 108-114, 2010.

[5] B. Prasad and L. Lewis, Distance Education at Degree-Granting Postsecondary Institutions: 2006-2007, Washington, DC: U.S. Government Printing Office, 2008.

[6] S. Choy. (2002). Findings from the condition of education 2002: nontraditional undergraduates. [Online]. Available: http://nces.ed.gov/programs/coe/2002/analyses/nontraditional/index.a $\mathrm{sp}$

[7] J. M. Ross-Gordon, "Adult learners in the classroom," New Directions for Student Services, pp. 43, Summer 2003.

[8] C. E. Kasworm, "US adult higher education: One context of lifelong learning," International Journal of Continuing Education \& Lifelong Learning, vol. 5, pp. 1-19, 2012.

[9] M. Singh, "Adult education in selected countries in the asian region," A Reference for Policies, Programmes and Delivery Modes, Hamburg: UNESCO Institute for Education, 2002.

[10] M. S. Knowles, The Modern Practice of Adult Education: From Pedagogy to Andragogy (2nd ed.), Chicago: Follett: Cambridge, 1980.

[11] M. S. Knowles et al., The Adult Learner: The Definitive Classic in Adult Education and Human Resource Development, 7th edition, Oxford, Elsevier, 2011.

[12] S. B. Merriam, "Andragogy and self-directed learning: Pillars of adult learning theory," in The New Update on Adult Learning Theory. New Directions for Adult and Continuing Education, S. Merriam, ed., vol. 89, San Francisco: Jossey-Bass, 2001, pp. 3-13.

[13] J. M. Ross-Gordon, "Research on Adult Learners: Supporting the Needs of a Student Population that Is No Longer Nontraditional," Peer Review, vol. 13, pp. 26-29, Winter 2011.

[14] P. C. Candy, Self-Direction for Lifelong Learning, San Francisco: Jossey-Bass, 1991.

[15] G. Grow, "Teaching Learners to Be Self-Directed: A Stage Approach," Adult Education Quarterly, vol. 41, pp. 125-149, 1991.

[16] J. M. Mezirow, "Learning to Think Like an Adult: Core Concepts of Transformation Theory," in Learning as Transformation: Critical Perspectives on a Theory in Progress, J. M. Mezirow, ed., San Francisco: Jossey-Bass, pp. 3-33, 2000.

[17] P. Cranton, "Self-directed and transformative instructional development," Journal of Higher Education, vol. 65, pp. 726-744, 1994.

[18] J. Sandars and M. Langlois, "E-learning and the educator in primary care: Responding to the challenge," Education for Primary Care, vol. 16, pp. 129-133, 2005

[19] D. E. Douglas and G. Van Der Vyver, "Effectiveness of e-learning course materials for learning database management systems: An experimental investigation," Journal of Computer Information Systems, vol. 44, pp. 41-48, 2004.

[20] J. Keengwe and T. T. Kidd, "Towards best practices in online learning and teaching in higher education," MERLOT Journal of Online Learning and Teaching, vol. 6, 2010. 
[21] J. C. Richardson and K. Swan, "Examining social presence in online courses in relation to students' perceived learning and satisfaction," Journal of Asynchronous Learning Network, vol. 7, 2003.

[22] F. Belanger and D. H. Jordan, Evaluation and Implementation of Distance Learning: Technologies, Tools and Techniques, Hershey, P. A.: Idea Group Pub, 2000.

[23] I. Allen and J. Seaman, Growing by Degrees: Online Education in the United States, Needham, M. A.: The Sloan Consortium, 2005.

[24] S. Junaidu, "Effectiveness Of Multimedia In Learning \& Teaching Data Structures Online," Turkish Online Journal of Distance Education-TOJDE, vol. 9, pp. 97-107, 2008.

[25] D. P. Diaz and R. B. Cartnal, "Students' learning styles in two classes: Online distance learning and equivalent on-campus," College Teaching, vol. 47, pp. 130-135, 1999.

[26] S. S. Liaw et al., "An activity-theoretical approach to investigate learners factors toward e-learning systems," Computers in Human Behavior, vol. 23, 2007.

[27] M. G. Moore, "What does research say about learners using computer-mediated communication in distance learning," The American Journal of Distance Education, vol. 16, pp. 61-64, 2002.

[28] P. C. Sun et al., "What drives a successful eLearning? An empirical investigation of the critical factors influencing learner satisfaction," Computers \& Education, vol. 50, 2008.

[29] L. A. Ho and T. H. Kuo, "How can one amplify the effect of e-learning? An examination of high-tech employees computer attitude and flow experience," Computers in Human Behavior, vol. 26, 2010.

[30] H. Peng et al., "University students self-efficacy and their attitudes toward the Internet: The role of students perceptions of the Internet,' Educational Studies, vol. 32, pp. 73-86, 2006.

[31] G. Piccoli et al., "Web-based virtual learning environments: a research framework and a preliminary assessment of effectiveness in basic IT skill training," MIS Quarterly, vol. 25, pp. 401-426, 2001.

[32] K. A. Pituch and Y.-K. Lee, "The influence of system characteristics on e-learning use," Computers \& Education, vol. 47, 2006.

[33] H. M. Selim, "Critical success factors for e-learning acceptance: Confirmatory factor models," Computers \& Education, vol. 49, 2007.

[34] Y. Yang and N. C. Lin, "Internet perceptions, online participation and language learning in Moodle forums:A case study on nursing students in Taiwan," Procedia Social and Behavioral Sciences, vol. 2, 2010.

[35] R. B. Fich and S. R. Hiltz, "Impacts of asynchronous learning networks on individual and group problem solving: A field experiment," Group Decision and Negotiation, vol. 8, pp. 409-426, 1999.

[36] P. Hanson and R. Robson, "Evaluating course management technology: A pilot study," vol. 24, CO: Educause Center for Applied Research, 2004.

[37] R. A. Ellis et al., "Engineering students' conceptions of and approaches to learning through discussions in face-to-face and online contexts," Learning an Instruction, vol. 18, pp. 267-282, 2008.

[38] S. Lonn and S. D. Teasley, "Saving time or innovating practice: Investigating perceptions and uses of Learning Management Systems,' Computers \& Education, vol. 53, pp. 686-694, 2009.

[39] S. Roehm and W. Bonnel, "Engaging students for learning with online discussions," Teaching and Learning in Nursing, vol. 4, pp. 6-9, 2009.

[40] R. B. Woodruff et al., "Modeling consumer satisfaction processes using experience-base d norms," Journal of Marketing Research, vol. 20, pp. 296-304, 1983.
[41] E. R. Cadotte et al., "Expectations and norms in models of consumer satisfaction," Journal of Marketing Research, vol. 24, pp. 305-314, 1987.

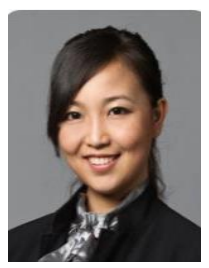

Guan Chong is a marketing lecturer in the School of Business at the SIM University (UniSIM), Singapore, where she has been a faculty member since 2011. Before joining UniSIM, Chong had taught marketing courses at the Nanyang Technological University (NTU), Singapore, for three years. Chong completed her Ph.D. in marketing at Nanyang Business School, NTU, and her undergraduate studies in marketing at Peking University,

China.

Her research interests lie in the area of online consumer decision making and online social media. Her publications appear in journals including psychology \& marketing, database and International Journal of Virtual Communities and Social Networking. She has also published several book chapters and presented her research at major conferences such as the Informs Marketing Science. She had taught courses in marketing, including research methods, multivariate analysis, marketing and case studies in marketing management.

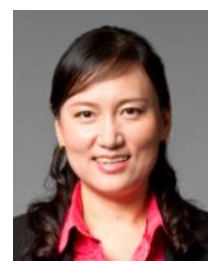

Ding Ding obtained her $\mathrm{PhD}$ in economics from Nanyang Technological University, Singapore, in 2010. She is a chartered financial analyst (CFA) and a member of the Economics Society of Singapore.

She is currently the head of Bs. finance programme in the School of Business at SIM University, Singapore, where she has been a faculty member since 2008 . Before joining UniSIM, she had been teaching and doing research in economics at NTU for three years.

Dr Ding has developed and taught courses in economics and finance, such as financial instruments and markets, cooperate finance and managerial economics. Her current research interests include international economics, development economics, Chinese economy, capital markets, and monetary policy. She has published book chapters and articles in journals such as North American Journal of Economics and Finance.

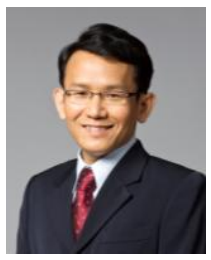

Kong Weng Ho obtained his $\mathrm{PhD}$ in economics, University of Chicago, USA, 1998.

$\mathrm{He}$ is an associate professor (teaching) with the Department of Economics, National University of Singapore, 1 Arts Link, Singapore 117570. He has taught at SIM University and the Nanyang Technological University. He has published journal articles in Social Indicators Research, Journal of Asian Economics, and Evaluation and Program Planning. $\mathrm{He}$ is a co-author of YOUTH.sg: The State of Youth in Singapore (Singapore: National Youth Council, 2011). His current research interests are class response system and learning outcomes, commitment and subjective well-being, identity and happiness, inequality and social mobility, and economic and non-economic well-being of low-income families under the Work Support Programme in Singapore.

Prof. Ho is a family research advisor of the Ministry of Social and Family Development, Singapore. He has won the University Excellent Teacher Award at the National University of Singapore three times, and the Faculty of Arts and Social Sciences Excellent Teaching Award twice. 